\title{
KONTRIBUSI KECERDASAN EMOSIONAL DAN KECERDASAN SOSIAL TERHADAP KINERJA PEGAWAI PADA ORGANISASI PERANGKAT DAERAH KABUPATEN TANAH DATAR
}

\author{
Yeyen Oktaviani \\ Jurusan Administrasi Publik, Fakultas Ilmu Sosial, Universitas Negeri Padang \\ yeyenoktaviani0210@gmail.com

\section{Syamsir} \\ Jurusan Administrasi Publik, Fakultas Ilmu Sosial, Universitas Negeri Padang \\ syamsirsaili@yahoo.com
}

\begin{abstract}
This study aimed to determine the contribution of emotional intelligence and social intelligence on the performance of employees in the Local Apparatus Organization of Tanah Datar Regency. This study was motivated by various problems which indicated the low quality of employee performance which was allegedly related to the low emotional intelligence and social intelligence of the employees. This was a quantitative research whose population was all civil servants in the organization totaling 1.596 people. The sample in this study consisted of 320 respondents who were determined using the Slovin formula with an error rate of 5\% and set through Multistage Random Sampling technique. Data in this study were collected trough questionnaires with Likert scale measurement and analyzed with multiple linear regression test. The results of this study showed that there was a contribution of emotional intelligence to employee performance by $41,3 \%$. There was also a contribution of social intelligence to employee performance amounted to $48,3 \%$. At the same time, the contribution of emotional and social intelligence on the performance of employees in the Local Apparatus Organization of Tanah Datar Regency were $53,2 \%$. So it could be concluded that emotional intelligence and social intelligence contributed significantly to employee performances.
\end{abstract}

Keywords: Emotional intelligence, social intelligence, and performance

How to Cite: Yeyen Oktaviani and Syamsir. 2018. Kontribusi Kecerdasan Emosional dan Kecerdasan Sosial Terhadap Kinerja Pegawai Pada Organisasi Perangkat Daerah Kabupaten Tanah Datar. 1(1): pp. 147-158. DOI: https://doi.org/10.24036/jess/vol2-iss2

\section{Pendahuluan}

Manajemen sumber daya manusia (MSDM) merupakan salah satu instrumen penting bagi organisasi dalam mencapai berbagai tujuannya. Tujuan yang ingin dicapai melalui proses-proses manajemen sumber daya manusia adalah sumber daya manusia professional, yang memiliki karakteristik berakhlak mulia, kompeten, dan termotivasi. Marwansyah (2012) mengatakan sumber daya 
manusia profesional adalah SDM yang memiliki kecerdasan spiritual, kecerdasan emosional, kecerdasan intelektual, dan kecerdasan kinestik.

Organisasi Perangkat Daerah atau biasa disebut OPD adalah perangkat Pemerintah Daerah di Provinsi maupun Kabupaten. Organisasi Perangkat Daerah (OPD) adalah pelaksana fungsi eksekutif yang harus berkoordinasi agar penyelenggaraan pemerintahan berjalan dengan baik. Kabupaten Tanah Datar memiliki 39 Organisasi Perangkat Daerah. Dinas Kependudukan dan Pencatatan Sipil merupakan salah satu Organisasi Perangkat Daerah di Kabupaten Tanah Datar. Berdasarkan pengalaman penulis pada saat mengikuti kegiatan magang di Kantor Dinas Kependudukan dan Pencatatan Sipil pada Bulan Juli - Agustus 2017, masih ditemukan beberapa permasalahan kinerja yang terjadi pada organisasi ini. Dari pengamatan awal, penulis melihat masih terdapat masalah terkait dengan masih kurangnya kinerja pegawai di Dinas kependudukan dan Pencatatan Sipil Kabupaten Tanah Datar. Hal ini dibuktikan dengan masih adanya pegawai yang kurang disiplin seperti datang terlambat, membolos saat jam kerja dengan alasan menjemput anak sekolah dan berbagai alasan lainnya, dan bahkan datang hanya untuk mengambil absen saja yang selanjutnya pegawai tidak akan berada di ruangan kerjanya pada saat jam kerja. Hal ini didukung dengan hasil wawancara yang penulis lakukan dengan salah satu masyarakat dalam bulan Agustus 2017:

...enak kalau ada anak magang ini, cepat diproses dokumennya kalau pegawai jam segini pada masih duduk-duduk di kantin, padahal sudah jam kerja. Biasanya masyarakat harus menunggu pegawai hanya untuk pemeriksaan kelengkapan dokumen belum lagi pemberian nomor antri yang lama, ditambah juga harus ngantri di loket depan.

Sebagai pelayan masyarakat, pegawai yang bekerja di lingkungan Organisasi Perangkat Daerah harus memberikan pelayanan yang terbaik kepada masyarakat karena indikator kinerja mereka salah salah satunya ditentukan oleh seberapa puas masyarakat mendapat pelayanan dari pegawai. Di sisi lain banyaknya masyarakat yang membutuhkan layanan yang cepat membuat pegawai harus bertindak cepat. Ketidakmampuan memenuhi harapan masyarakat akan berujung pada caci maki dan sumpah serapah. Namun pada kenyataannya masih ada pegawai yang bermalas-malasan dalam bekerja.

Selain itu juga masih kurangnya motivasi pegawai dalam melakukan pelayanan kepada masyarakat, seperti kurang semangatnya pegawai dalam melakukan pekerjaan sesuai dengan tugas dan fungsinya. Kurangnya motivasi pegawai juga terlihat dari hasil wawancara percakapan yang terjadi antara penulis dengan salah satu pegawai di Dinas Kependudukan dan Pencatatan Sipil Kabupaten Tanah Datar dalam bulan juli 2017: “...mau rajin atau malas bekerja gaji yang diberikan akan tetap segitu juga, maka kita kerjanya santai saja, tidak usah terlalu rajin."

Selanjutnya pegawai di Dinas Kependudukan dan Pencatatan Sipil Kabupaten Tanah Datar juga masih suka menunda-nunda pekerjaan yang membuat menumpuknya pekerjaan. Biasanya pegawai akan mengerjakan pekerjaan yang tertunda apabila sudah dekat dengan batas waktu yang ditentukan, 
yang membuat pegawai terpaksa lembur dan memberi dampak stresnya pegawai dalam penyelesaian pekerjaannya tersebut.

Disamping itu melalui pengamatan penulis selama magan di Dinas Kependudukan dan Pencatatan Sipil Kabupaten Tanah Datar, juga masih ditemui keluhan masyarakat terkait dengan tidak ramahnya pegawai dalam memberikan pelayanan kepada masyarakat. Masih adanya perbedaan pelayanan terhadap masyarakat dengan orang yang kenal dengan pegawai di lingkungan Dinas Kependudukan dan Pencatatan Sipil Kabupaten Tanah Datar. Hal ini ditunjukkan dengan masih adanya pembuatan dokumen oleh orang yang kenal dengan pegawai tanpa melalui prosedur yang telah ditetapkan. Untuk sesama pegawai juga masih ditemukan ketidakakuran antara pegawai. Hal ini dapat dilihat dari masih adanya pegawai yang saling menjelek-jelekan pegawai lainnya.

Permasalahan lain juga muncul dengan kurangnya kerjasama antara pegawai di Disdukcapil Tanah Datar yang tergambar dari tersendatnya pelayanan apabila ada pegawai yang mengikuti kegiatan dinas luar dan pegawai lain tidak mau mengisi posisi pegawai tersebut dalam melakukan pelayanan kepada masyarakat. Hal ini juga berakibat protes masyarakat karena lambatnya pelayanan yang pada ujungnya membuat adanya perdebatan antara pegawai di Disdukcapil Tanah Datar dan masyarakat.

Selain itu, masih ada masih banyaknya fenomena oknum pemerintah yang bersikap dan berpola-laku arogan. Salah satunya kasusnya yaitu masalah dugaan sikap arogan dan pelecehan terhadap wartawan yang dilakukan oleh oknum Pegawai Negeri Sipil (PNS) berinisial "MD" yang bertugas di instansi Penanaman Modal Pelayanan Satu Pintu dan Tenaga Kerja (PMPTSP-Naker) Kabupaten Tanah Datar (Sumbar Kabar Daerah, 2018).

Berdasarkan gejala yang telah dijelaskan di atas, maka dapat disimpulkan bahwa banyak faktor yang mempengaruhi kinerja pegawai mulai dari disiplin pegawai, sikap pegawai termasuk kecerdasan emosional dan kecerdasan sosial pegawai. Berdasarkan dari permasalahan di atas maka ada beberapa masalah yang berkaitan dengan faktor-faktor kecerdasan emosional pegawai seperti kurangnya motivasi pegawai dalam bekerja dan masih ada pegawai yang kurang mampu mengelola emosinya yang terindikasi melalui masih adanya perdebatan antara pegawai dan masyarakat dan pegawai masih belum mampu mengelola stress yang disebabkan oleh tuntutan pekerjaan. Selanjutnya, permasalahan yang bersangkutan dengan kecerdasan sosial pegawai adalah tidak ramahnya pegawai dalam memberikan pelayanan kepada masyarakat, ketidakakuran sesama pegawai, kurangnya kerjasama tim, dan masih adanya sikap arogan dari pegawai.

Hal lain yang menjadi dasar peneliti untuk melakukan penelitian ini dikarenakan masih minim kajian-kajian tentang dampak kecerdasan emosional dan kecerdasan sosial di organisasi publik. Meskipun kajian-kajian ilmiah sudah banyak memberikan bukti bahwa kecerdasan emosional dan kecerdasan sosial adalah salah satu faktor penting bagi kinerja seseorang atau tim. Namun hal tersebut belum banyak dibuktikan di organisasi publik karena kebanyakan kajiankajian tersebut menggunakan setting organisasi swasta. Menurut Ely Susanto (dalam Pramusinto, 2009) ada beberapa alasan kenapa kajian-kajian kecerdasan emosional dan kecerdasan sosial menarik untuk dilakukan di organisasi publik. 
Pertama, pengukuran kinerja organisasi swasta lebih jelas dan mudah dipahami, sedangkan pengukuran kinerja sektor publik lebih sulit dioperasionalkan. Kedua, dalam pengambilan keputusan organisasi publik melibatkan lebih banyak kelompok kepentingan yang beragam. Ketiga, semua kegiatan dan kebijakan yang dibuat oleh organisasi publik selalu dimonitor oleh media massa dan masyarakat sehingga prinsip kehati-hatian menjadi prioritas sedang sektor swasta relatif tidak mengalami hal tersebut. Perbedaan-perbedaan keadaan antara organisasi publik dan swasta tersebut akan membawa pengaruh yang berbeda terhadap perilaku setiap pegawainya, yang nanti juga akan berpengaruh terhadap tingkat stres dan masalah psikologis lainnya sehingga kajian-kajian tentang kecerdasan emosional dan kecerdasan sosial di organisasi publik sangat menarik untuk dilakukan.

Berdasarkan latar belakang masalah di atas, maka penulis telah melakukan penelitian penelitian di Kabupaten Tanah Datar tentang kontribusi kecerdasan emosional dan kecerdasan sosial di Organisasi Perangkat Daerah Kabupaten Tanah Datar. Rumusan Masalah yang dikemukakan dalam penelitian ini adalah:

1. Apakah terdapat kontribusi kecerdasan emosional terhadap kinerja pegawai di Organisasi Perangkat Daerah (OPD) Kabupaten Tanah Datar?

2. Apakah terdapat kontibusi kecerdasan sosial terhadap kinerja pegawai di Organisasi Perangkat Daerah (OPD) Kabupaten Tanah Datar?

3. Apakah terdapat kontribusi kecerdasan emosional dan kecerdasan sosial terhadap kinerja pegawai di Organisasi Perangkat Daerah (OPD) Kabupaten Tanah Datar?

\section{Tinjauan Kepustakaan}

\section{Kinerja}

Menurut Torang (2013), kinerja adalah kuantitas dan atau kualitas hasil kerja individu atau sekelompok di dalam organisasi dalam melaksanakan tugas pokok dan fungsi yang berpedoman pada norma, standar operasional prosedur, kriteria dan ukuran yang telah ditetapkan atau yang berlaku dalam organisasi. Mangkunegara (dalam Pasolong, 2013) mengatakan bahwa kinerja merupakan hasil kerja secara kualitas dan kuantitas yang dicapai oleh seseorang dalam melaksakan fungsinya sesuai dengan tanggung jawab yang diberikan kepadanya .

Selanjutnya Cascio (dalam Wibowo, 2016) menjelaskan kinerja sebagai cara untuk memastikan bahwa pekerja individual atau tim tahu apa yang diharapkan dari mereka dan mereka tetap fokus pada kinerja efektif dengan memberikan perhatian pada tujuan, ukuran dan penilaian. Dari beberapa penjelasan diatas dapat disimpulkan bahwa kinerja adalah hasil kerja yang dicapai oleh seorang individu, kelompok, dan organisasi dalam melaksanakan wewenang dan tanggung jawab masing-masing dalam mencapai tujan yang telah ditetapkan sebelumnya.

\section{Kecerdasan Emosional dan Kecerdasan Sosial}

Mayer dan Salovey (dalam Pramusinto, 2009) mendefinisikan kecerdasan emosional (emotional intelligence) sebagai kemampuan untuk mengevaluasi dan mengekpresikan emosinya sendiri, kemampuan untuk mengenali dan memahami emosi orang lain, kemampuan untuk mengatur emosinya sendiri dan sekaligus 
emosi orang lain, dan kemampuan untuk menggunakan emosinya dalam rangka mencapai kinerja yang lebih baik. Sementara Marwansyah (2014) menyatakan bahwa kecerdasan emosional adalah kapasitas untuk memahami emosi kita dan mengelolanya secara efektif dan untuk memahami dan efektif mengelola emosi orang lain.

Ciri-ciri kecerdasan emosional meliputi kemampuan untuk memotivasi diri sendiri dan bertahan ketika menghadapi sebuah masalah yang membuat frustasi, mengendalikan dorongan hati dan tidak melebih-lebihkan perasaan ketika sedang bergembira, mengatur suasana hati dan menjaga agar beban pikiran ketika menumpuk tidak melumpuhkan kemampuan dalam berpikir, berempati, dan berdoa. Dari penjelasan diatas dapat diambil kesimpulan bahwa kecerdasan emosional adalah kemampuan untuk mengenali perasaan orang lain dan diri sendiri serta kemampuan memantau perasaan orang lain dan diri sendiri, dan juga memilah-milah semuanya agar dapat membimbing pikiran dan tindakan.

Selanjutnya, kecerdasan sosial (social intelligence) menurut Thordike (dalam Goleman, 2006) mendefinisikan kecerdasan sosial atau adalah kemampuan untuk memahami pria dan wanita, laki-laki dan perempuan, serta bertindak secara bijak dalam hubungan manusia. Kecerdasan sosial juga disebut interpersonal intelligence yaitu orang yang mampu memahami, berinteraksi, dan berhubungan baik dengan orang lain yang meliputi kemampuan memahami orang lain, kemampuan sosial, dan keterampilan menjalin hubungan. Aldily (2017) menjelaskan inti dari social intelligence yaitu kemampuan untuk merasakan keadaan internal, motivasi, dan perilaku diri sendiri dan orang lain, serta bertindak kepada orang lain secara optimal berdasarkan informasi tersebut. Dari penjelasan di atas dapat diambil kesimpulan bahwa kecerdasan sosial adalah kemampuan yang dimiliki seseorang dalam berinteraksi, bergaul, memahami dan bekerja sama dengan orang lain dalam keadaan yang berbeda-beda dengan menggunakan keterampilan-keteranpilan sosial yang dimiliki.

\section{Kecerdasan Emosional dan Kecerdasan Sosial dalam Kinerja Pelayanan Publik}

Pada organisasi pemerintah yang berorientasi pelayanan publik, ukuran pencapaian tujuan organisasi dapat dilihat berdasarkan kepuasan masyarakat terhadap kinerja dari aparatur atau pegawai pemerintah. Mangkunegara (2009) mengemukakan bahwa dalam hubungannya dengan pencapaian kinerja yang tinggi, perlu dilandaskan pada beberapa pendekatan, diantaranya adalah pendekatan psikologis dan organisasi. Pendekatan psikologis terhadap kinerja salah satunya adalah pendekatan terhadap kecerdasan emosional dan kecerdasan sosial dari sumber daya manusia yang ada dalam organisasi.

Goleman dalam Khairunnisa (2015) mengungkapkan bahwa "setinggitingginya kecerdasan intelektual menyumbang kira-kira $20 \%$ bagi faktor-faktor yang menentukan sukses individu dalam hidup, sedangkan $80 \%$ lainnya dipengaruhi oleh kekuatan-kekuatan lain termasuk diantaranya kecerdasan emosional dan kecerdasan sosial". Marwansyah (2012) menyatakan bahwa kecerdasan emosional merujuk pada keterampilan, kapabilitas, dan kompetensi non-kognitif yang mempengaruhi kemampuan seseorang untuk berhasil menghadapi tuntutan dan tekanan lingkungan. 
Seseorang yang memiliki kecerdasan emosional yang baik akan mampu membuat keputusan yang tegas dan tepat walaupun di hadapkan pada tuntutan kerja yang berat dan tekanan di lingkungan kerja. Seseorang yang memiliki kecerdasan emosional akan dapat menunjukan integritasnya, mampu berpikir jernih dalam keadaan tertekan, bertindak sesuai etika, berpegang pada prinsip, dan memiliki dorongan untuk berprestasi. Kecerdasan emosional akan membuat individu menggunakan emosi secara efektif untuk mencapai tujuan dengan tepat, membangun hubungan kerja yang produktif dan meraih prestasi ditempat kerja.

Ely Susanto dalam Pramusinto (2009) menyatakan kecerdasan emosional birokrat bisa meningkatkan kinerja pelayanan kepada masyarakat karena: (1) dengan memahami kondisi emosi dirinya sendiri dan kondisi emosi masyarakat yang dilayani, seorang birokrat akan mampu menjaga hubungan baik dengan masyarakat yang dilayani, (2) dengan kecerdasan emosional seorang birokrat akan mampu mengontrol dan mengelola stress sehingga dampaknya tidak sampai kepada masyarakat yang dilayani, (3) kecerdasan emosional akan membantu seorang birokrat untuk berkomunikasi dengan baik dan lancar.

Selain dari kecerdasan emosional salah satu yang mempengaruhi kinerja adalah kecerdasan sosial. Aldily (2017) mendefinisikan kecerdasan sosial sebagai kemampuan seseorang dalam berinteraksi, bergaul, memahami, dan bekerja sama dengan orang lain dalam situasi yang berbeda-beda dengan menggunakan keterampilan-keterampilan sosial yang dimiliki. Goleman dan Boyatziz (dalam Putra dan Nutjahjanti, 2017) mengungkapkan bahwa pegawai dalam pekerjaannya perlu memiliki kecerdasan sosial agar dapat menghasilkan kerja sama yang baik di lingkungan pekerjaannya. Dengan memiliki kecerdasan sosial yang tinggi pegawai dimungkinkan untuk dapat memberikan kontribusi yang efektif bagi suatu tim kerja di dalam organisasi.

\section{Metode Penelitian}

Penelitian ini adalah penelitian kuantitatif. Pendekatan yang digunakan di dalam penelitian, proses, hipotesis, turun ke lapangan, analisa data dan kesimpulan data sampai dengan penulisan laporan dalam penelitian ini menggunakan aspek pengukuran, perhitungan, rumus, dan kepastian data numerik. Populasi dalam penelitian ini adalah pegawai negeri sipil yang berada dalam lingkup Organisasi Perangkat Daerah (OPD) Kabupaten Tanah Datar yang berjumlah 1.596 orang. Sampel dalam penelitian ini terdiri dari 320 pegawai negeri sipil yang ditentukan dengan menggunakan rumus Slovin dengan tingkat kesalahan 5\%. Teknik pengambilan sampel yang digunakan dalam penelitian ini adalah teknik Multistage Random Sampling.

Teknik pengumpulan data dalam penelitian ini menggunakan angket yang disebarkan kepada responden dengan pengukuran skala likert dan menggunakan 4 opsi jawaban (sangat setuju, setuju, kurang setuju, dan tidak setuju). Teknik analisis data yang digunakan adalah regresi linear berganda yang didahului dengan uji asumsi klasik sebagaimana dipersyaratkan dalam uji regresi. Selain itu untuk mendapatkan gambaran umum tentang kedua variabel juga digunakan frekuensi, mean, dan TCR (Tingkat Capaian Responden). 


\section{Hasil Penelitian Dan Pembahasan}

\section{Hasil Penelitian}

Sebagaimana telah dikemukakan dalam bagian pendahuluan, penelitian ini ingin menjawab tiga pertanyaan penelitian atau rumusan masalah. Rumusan masalah pertama adalah: apakah terdapat kontribusi kecerdasan emosional terhadap kinerja pegawai di Organisasi Perangkat Daerah Kabupaten Tanah Datar? Untuk menjawab pertanyaan penelitian dapat dilihat analisis data temuan penelitian seperti disajikan pada Tabel 1 berikut:

Tabel 1. Kontribusi dan Uji Anova Variabel Kecerdasan Emosional terhadap Kinerja Pegawai di OPD Kabupaten Tanah Datar

\begin{tabular}{lcc}
\hline \multicolumn{1}{c}{ Variabel } & $\begin{array}{c}\text { Hasil Kontribusi } \\
\text { Adjusted } \boldsymbol{R} \text { Square }\end{array}$ & $\begin{array}{c}\text { Hasil Uji Anova } \\
\text { (F) Sig. }\end{array}$ \\
\hline $\begin{array}{l}\text { Kecerdasan Emosional } \\
\text { tehadap Kinerja Pegawai }\end{array}$ & .413 & .000 \\
\hline
\end{tabular}

Berdasarkan tabel di atas dapat dijelaskan bahwa hasil nilai Adjusted $R$ Square yang didapatkan dari analisis regresi adalah sebesar 0,413 , yang artinya kontribusi kecerdasan emosional terhadap kinerja pegawai sebesar $41,3 \%$. Sementara sisanya sebesar 58,7\% merupakan kontribusi yang diberikan oleh variabel lain. Selanjutnya, berdasarkan hasil Uji Anova (F) pada tabel di atas dapat dilihat bahwa hasil atau angka signifikansi kontribusi menunjukan angka 0,000, yang yang berarti habwa variabel kecerdasan emosional berkontribusi terhadap kinerja pegawai. Dengan demikian dapat disimpulkan bahwa Ho dalam dalam penelitian ditolak dan Ha diterima yang berarti terdapat kontribusi kecerdasan emosional terhadap kinerja pegawai di Organisasi Perangkat Daerah Kabupaten Tanah Datar.

Selanjutnya, rumusan masalah kedua yang ingin dijawab didalam penelitian ini adalah: apakah terdapat kontribusi kecerdasan sosial terhadap kinerja pegawai di Organisasi Perangkat Daerah Kabupaten Tanah Datar? Untuk menjawab pertanyaan penelitian dapat dilihat analisis data temuan penelitian seperti disajikan pada Tabel 2 berikut:

Tabel 2. Kontribusi dan Uji Anova Variabel Kecerdasan Sosial terhadap Kinerja Pegawai di OPD Kabupaten Tanah Datar

\begin{tabular}{lcc}
\hline \multicolumn{1}{c}{ Variabel } & $\begin{array}{c}\text { Hasil Kontribusi } \\
\text { Adjusted } R \text { Square }\end{array}$ & $\begin{array}{c}\text { Hasil Uji Anova } \\
\text { (F) Sig. }\end{array}$ \\
\hline $\begin{array}{l}\text { Kecerdasan Sosial tehadap } \\
\text { Kinerja Pegawai }\end{array}$ & .483 & .000 \\
\hline
\end{tabular}


Berdasarkan tabel di atas dapat di pahami bahwa, nilai Adjusted $R$ Square sebesar 0,483 , yang artinya kontribusi kecerdasan sosial terhadap kinerja pegawai sebesar 48,3\%. Sisanya sebesar 51,7\% merupakan kontribusi yang diberikan oleh variabel lain. Selanjutnya, berdasarkan hasil Uji Anova (F) pada tabel di atas dapat dilihat bahwa hasil atau angka signifikansi kontribusi menunjukan angka 0,000, yang artinya variabel kecerdasan sosial berkontribusi terhadap kinerja pegawai. Dengan demikian dapat pula disimpulkan bahwa Ho ditolak dan $\mathrm{Ha}$ diterima yang berarti terdapat kontribusi kecerdasan sosial terhadap kinerja pegawai di Organisasi Perangkat Daerah Kabupaten Tanah Datar.

Selanjutnya, rumusan masalah ketiga yang ingin dijawab dalam penelitian ini adalah: apakah terdapat kontribusi kecerdasan emosional dan kecerdasan sosial secara simultan terhadap kinerja pegawai di Organisasi Perangkat Daerah Kabupaten Tanah Datar? Secara ringkas, hasil pengujian regresi untuk menjawab pertanyaan penelitian ini dapat dilihat pada Tabel 3 berikut ini:

Tabel 3. Kontribusi dan Uji Anova Variabel Kecerdasan Emosional dan Kecerdasan Sosial terhadap Kinerja Pegawai di OPD Kabupaten Tanah Datar

\begin{tabular}{lcc}
\hline \multicolumn{1}{c}{ Variabel } & $\begin{array}{c}\text { Hasil Kontribusi } \\
\text { Adjusted } \boldsymbol{R} \text { Square }\end{array}$ & $\begin{array}{c}\text { Hasil Uji Anova } \\
\text { (F) Sig. }\end{array}$ \\
\hline $\begin{array}{l}\text { Kecerdasan Emosional dan } \\
\text { Kecerdasan Sosial terhadap }\end{array}$ & .532 & .000 \\
Kinerja Pegawai & & \\
\hline
\end{tabular}

Berdasarkan Tabel 3 di atas dapat dipahami bahwa nilai Adjusted $R$ Square sebesar 0,532, yang yang berarti bahwa kecerdasan emosional dan kecerdasan sosial secara bersama-sama (simultan) berkontribusi terhadap kinerja sebesar $53,2 \%$. Sisanya sebesar $46,8 \%$ merupakan kontribusi yang diberikan oleh variabel lain yang tidak diteliti dalam penelitian ini. Selanjutnya dilihat dari hasil Uji Anova (F) didapatkan hasil signifikansi sebesar 0,000 yang berarti bahwa kecerdasan emosional dan kecerdasan sosial berkontribusi terhadap kinerja pegawai, dan kebenaran hasil atau kesimpulan hasil uji ini dapat dipercaya sampai dengan $100 \%$. Dengan demikian dapat pula disimpulkan bahwa Ho ditolak dan Ha diterima dan hal ini berarti bahwa kecerdasan emosional dan kecerdasan sosial secara bersama-sama berkontribusi terhadap kinerja pegawai di Organisasi Perangkat Daerah Kabupaten Tanah Datar.

\section{Pembahasan}

Berdasarkan hal uji regresi secara parsial sub variabel Kecerdasan Emosional (X1) terhadap variabel kinerja pegawai (Y) di Organisasi Perangkat Daerah (OPD) Kabupaten Tanah Datar didapatkan hasil bahwa, nilai Adjusted R Square sebesar 0,413 , yang artinya kontribusi kecerdasan emosional terhadap kinerja pegawai sebesar $41,3 \%$. Selanjutnya berdasarkan hasil uji annova (F) didapatkan nilai 
signifikansi sebesar 0.000 , karena signifikansi uji nilainya lebih kecil dari 0,05 dan dapat disimpulkan bahwa variabel kecerdasan emosional berkontribusi terhadap kinerja pegawai. di Organisasi Perangkat Daerah (OPD) Kabupaten Tanah Datar.

Menurut Mayer dan Salovey (dalam Pramusinto, 2009) kecerdasan emosional adalah kemampuan untuk mengevaluasi dan mengekpresikan emosinya sendiri, kemampuan untuk mengenali dan memahami emosi orang lain, kemampuan untuk mengatur emosinya sendiri dan sekaligus emosi orang lain, dan kemampuan untuk menggunakan emosinya dalam rangka mencapai kinerja yang lebih baik. Dalam penelitian ini terlihat adanya kontribusi signifikan antara kecerdasan emosional terhadap kinerja pegawai. Hal ini dapat disebabkan karena adanya kemampuan mengelola emosi dan berpikir secara jernih akan mampu mengoptimalkan kinerja kognisinya sehingga mereka bisa berpikir jernih untuk menformulasikan kalimat-kalimat mana tepat untuk disampaikan kepada masyarakat sehingga masyarakat tidak sampai kecewa dan tersinggung sehingga kinerja pegawai akan meningkat.

Disamping itu hasil penelitian ini juga sejalan dengan pendapat yang dikemukakan oleh Setyaningrum, Utami, dan Ruhana (2016) yang mengemukakan adanya hubungan atau pengaruh lima komponen kecerdasan emosional terhadap kinerja karyawan, yaitu: 1) Kesadaran diri, dimana dengan kesadaran diri yang baik membuat seorang karyawan dapat tampil dengan keyakinan diri, sehingga dapat berbuat tegas dan mampu membuat keputusan yang baik dalam keadaan tidak pasti dan tertekan; 2) Pengaturan diri, dimana seseorang karyawan yang mampu mengatur emosi diri yang baik akan memiliki rasa tanggung jawab atas kinerjanya pribadi dan mempunyai kemampuan beradaptasi dalam menghadapi berbagai perubahan; 3) Motivasi, dimana adanya kemampuan untuk memotivasi diri sendiri akan membuat karyawan menjadi lebih semangat dalam bekerja, sehingga kinerjanya akan meningkat; 4) Empati, dimana adanya kemampuan berempati membuat seseorang menjadi mudah diterima banyak orang dan merasa diharga, begitu pula hal yang sama dirasakan orang lain yang merasa dirinya dihargai dengan pemikiran yang mempunyai perbedaan sudut pandang; dan 5) Keterampilan sosial, dimana keterampilan sosial yaitu kemampuan untuk menangani emosi dengan baik dan berinteraksi dengan lancar ketika berhubungan dengan orang lain, mempengaruhi dan memimpin orang lain, dapat menyelesaikan perselisihan dan untuk bekerja sama dalam tim.

Selain itu, berdasarkan hal uji regresi secara parsial sub variabel Kecerdasan Sosial (X2) terhadap variabel kinerja pegawai (Y) di Organisasi Perangkat Daerah (OPD) Kabupaten Tanah Datar didapatkan hasil bahwa, nilai Adjusted $R$ Square sebesar 0,483, yang artinya kontribusi kecerdasan sosial terhadap kinerja pegawai ada sebesar 48,3\%. Selain itu, berdasarkan hasil uji anova didapatkan nilai signifikansi sebesar 0.000 . Karena signifikansi uji nilainya lebih kecil dari 0,05 maka dapat disimpulkan bahwa variabel kecerdasan sosial berkontribusi terhadap kinerja pegawai dan kebenaran kesimpulal ini dapat dipercaya sampai dengan 100\%. Dengan demikian Ho dalam penelitian ini ditolak dan Ha diterima yang berarti terdapat kontribusi varaiabel kecerdasan sosial terhadap kinerja pegawai di Organisasi Perangkat Daerah (OPD) Kabupaten Tanah Datar. 
Penelitian ini menemukan bahwa adanya kontribusi signifikan dari kecerdasan social terhadap kinerja pegawai. Hal ini boleh jadi disebabkan oleh pandangan mereka bahwa apabila seorang pegawai memiliki kecerdasan sosial maka pegawai akan mau menerima pendapat dan masukan dari orang lain dengan baik sehingga akan bisa melakukan pekerjaan dengan baik.

Hasil penelitian ini senada dengan pendapat Goleman dan Boyatziz (dalam Putra dan Nurtjahjanti (2017) yang mengatakan bahwa individu dalam melakukan pekerjaannya perlu memiliki kecerdasan sosial agar dapat menghasilkan hasil kerjasama yang baik di lingkungan pekerjaan. Jika individu memiliki kecerdasan sosial, maka individu tersebut dapat lebih mendengarkan dan mempertimbangkan pandangan orang lain. Hal ini dapat menyebabkan individu untuk dapat memberikan kontribusi yang efektif bagi suatu tim kerja di dalam organisasi. Hal ini juga sejalan dengan hasil penelitian Santoso, Candraningrat, dan Binawati (2017) yang menemukan bahwa kecerdasan sosial berpengaruh positif terhadap kinerja.

Selanjutnya, berdasarkan hal uji regresi berganda, variabel Kecerdasan Emosional (X1) dan Kecerdasan Sosial (X2) terhadap variabel Kinerja Pegawai (Y) di Organisasi Perangkat Daerah (OPD) Kabupaten Tanah Datar didapatkan hasil bahwa nilai Adjusted $R$ Square sebesar 0,532, yang artinya kontribusi kecerdasan emosional dan kecerdasan sosial secara simultan terhadap kinerja pegawai adalah sebesar 53,2\%. Sisanya sebesar 46,8\% dipengaruhi oleh variabel lain yang tidak diteliti dalam penelitian ini. Berdasarkan hasil uji anova (F) didapatkan pula nilai signifikansi sebesar 0.000. Karena nilai signifikansi lebih kecil dari 0,05 maka dapat disimpulkan bahwa variabel kecerdasan emosional dan kecerdasan sosial secara simultan berkontribusi terhadap kinerja pegawai. Hal ini boleh jadi disebabkan karena adanya kemampuan pegawai mengelola emosi dengan baik dan mampu berpikir jernih serta mampu berinteraksi dengan baik dengan orang lain, sehingga hal ini menimbulkan kenyamanan bagi pegawai tersebut dan pada akhirnya dapat meningkatkan kinerja pegawai. Kondisi ini mungkin dapat dijelaskan oleh atau relevan dengan pendapat Pearce dan Randel (dalam Rosyad, Arifin dan Harismasakti, 2014) yang mengemukakan bahwa individu dengan kecerdasan emosional yang tinggi dapat menggunakan kemampuan mereka untuk mengelola emosi untuk mengembangkan hubungan sosial yang baik dan pada gilirannya akan mampu meningkatkan kinerja melalui saran dan dukungan sosial.

\section{Penutup}

Berdasarkan hasil penelitian dan pembahasan yang telah dijabarkan di atas, maka dalam penelitian ini dapat dikemukakan beberapa kesimpulan sebagai berikut.

1. Karena kecerdasan emosional (X1) berkontribusi terhadap kinerja pegawai dengan nilai Adjust $R$ Square 0,413 atau sebesar 41,3\%, maka hal ini berarti bahwa kecerdasan emosional seorang karyawan sangat dibutuhkan dalam menciptakan kinerja individu yang tinggi. Dalam penelitian ini kecerdasan emosional memiliki kontribusi yang signifikan terhadap kinerja pegawai; Sehingga Ho ditolak dan Ha diterima diterima dalam penelitian ini. 
2. Kecerdasan sosial (X2) juga memiliki kontribusi terhadap kinerja pegawai dengan nilai Adjust $R$ Square 0,483 atau berpengaruh sebesar 48,3\%. Hal ini juga berarti bahwa individu dalam melakukan pekerjaannya perlu memiliki kecerdasan sosial agar dapat menghasilkan hasil kerja sama yang baik di lingkungan pekerjaan. Dalam penelitian ini kecerdasan sosial memiliki kontribusi yang signifikan terhadap kinerja pegawai. Secara parsial nilai signifikansi variabel lebih kecil dari 0,05, maka Ho juga ditolak dan Ha diterima.

3. Secara simultan, kecerdasan emosional dan kecerdasan sosial juga berkontribusi terhadap kinerja pegawai di Organisasi Perangkat Daerah (OPD) Kabupaten Tanah Datar dengan nilai Adjust $R$ Square 0,532, yang artinya kontribusi kecerdasan emosional dan kecerdasan sosial secara simultan terhadap kinerja pegawai ada sebesar 53,2\%. Hal ini berarti bahwa seseorang yang memiliki kecerdasan emosional yang tinggi dapat menggunakan kemampuan mereka untuk mengelola emosi untuk mengembangkan hubungan sosial yang baik pada gilirannya meningkatkan kinerja melalui saran dan dukungan sosial.

Berdasarkan hasil penelitian dan kesimpulan yang telah dijelaskan di atas, maka penulis merekomendasikan saran-saran sebagai berikut:

1. Disarankan kepada pimpinan organisasi untuk melakukan pelatihan penyegaran kepada semua pegawai untuk dapat meningkatkan kecerdasan emosional dan kecerdasan sosial pegawai sehingga dapat meningkatkan kinerja pegawai.

2. Kepada pegawai untuk selalu melatih kecerdasan emosional dan kecerdasan sosial dalam bekerja dengan mengembangkan pikiran positif terhadap orang lain dan mau menerima masukan orang lain dengan baik sehingga dapat meningkatkan kenyaman dalam diri dan bisa meningkatkan kinerja dengan baik.

3. Peneliti menyadari bahwa hasil penelitian ini masih memiliki kelemahan tertentu, maka dari itu diharapkan kepada peneliti selanjutnya untuk lebih menyempurnakan penelitian ini dengan melibatkan lebih banyak variabel dan memperluas skop kajian agar lebih representatif hasilnya.

\section{DAFTAR KEPUSTAKAAN}

Aldily, Ridho. (2017). The Power of Social and Emotional Intelligence. Yogyakarta: Psikologi Corner.

Goleman, Daniel. (2006). Social Intelligence. Jakarta: PT. Gramedia Pustaka Utama.

Khairunnisa, Amalia. (2015). "Pengaruh Kemampuan Intelektual, Kecerdasan Emosional, dan Kecerdasan Spritual Terhadap Kinerja Auditor Inspektorat Provinsi Riau". Jom FEKON. Volume 2, No 2, 2015. 
Mangkunegara, Anwar Prabu. (2009). Evaluasi Kinerja SDM. Bandung: PT. Refika Aditama. . (2011). Manajemen Sumber Daya Manusia Perusahaan. Bandung: PT.Remaja Rosdakarya.

Marwansyah. (2012). Manajemen Sumber Daya Manusia. Bandung: Alfabeta. . (2014). Manajemen Sumber Daya Manusia. Bandung: Alfabeta.

Pasolong, Harbani. (2013). Kepemimpinan Birokrasi. Bandung: Alfabeta

Pramusinto, Agus. (2009). Reformasi Birokrasi, Kepemimpinan, dan Pelayanan Publik. Yogyakarta: Gava Media.

Putra, Eki Dwi \& Harlina Nurtjahjanti. (2017). "Hubungan Antara Kecerdasan Sosial Dengan Organizational Citizenship Behavior Pada Karyawan PT. Telkom Indonesia Regional IV Jawa Tengah dan di Yogyakarta". Jurnal Empati. Volume 6, No 4, 2017.

Rosyad, Soleh, M. Zaenal Arifin \& Eris Harismasakti. (2014). "Pengaruh Keecerdasan Emosional Terhadap Kinerja Pegawai Perguruan Tinggi La Tansa Mashiro di Rangkasbitung”. E-Jurnal Management. Volume 3, No 3, 2014 .

Setyaningrum, Rani, Hamidah Nayati Utami \& Ika Ruhana. (2016). "Pengaruh Kecerdasan Emosional Terhadap Kinerja". Jurnal Administrasi Bisnis. Volume 36, No 1, 2016.

Santoso, Rudi, Candraningrat \& Lilis Binawati. (2017). “ Elemen Kecerdasan Wirausaha Untuk Meningkatkan Kinerja Industri Kecil dan Menengah (IKM) Surabaya”. Jurnal Unesa. Volume 10, No 1, 2017.

Torang, Syamsir. (2013). Organisasi \& Manajemen. Bandung: Alfabeta

Wibowo. (2016). Manajemen Kinerja. Jakarta: PT. Raja Grafindo Persada. 